\author{
Екатерина С. Черепанова \\ Уральский федеральный университет \\ им. первого Президента России Б. Н. Ельцина \\ e.s.cherepanova@urfu.ru
}

Ekaterina S. Cherepanova

Ural Federal University

e.s.cherepanova@urfu.ru

\title{
ТЕМА СМЕРТИ В ЛИЧНОЙ КОРРЕСПОНДЕНЦИИ РУССКИХ УЧАСТНИКОВ ВОЙН 1939-1945 ГОДОВ: РЕАКЦИИ, РЕФЛЕКСИИ И ПРАКТИКИ ОПРАВДАНИЯ 1
}

\section{DEATH IN RUSSIAN SOLDIERS CORRESPONDENCE (1939-1945): REACTIONS, REFLECTION AND PRACTICES OF JUSTIFICATION}

В статье ставится задача раскрыть средствами философско-антропологического анализа особенность переживания человеком события смерти на войне с тем, чтобы обнаружить возможные ценностные ориентации, позволяющие судить о нравственных основаниях рефлексии о смерти и практиках ее оправдания. Методологически значимым в этом аспекте будут подходы П. Боянича, Г. Зиммеля, И. Ильина, Э. Левинаса и Ю. Хабермаса. Материалом для изучения являются опубликованные в различных изданиях письма участников советско-финской войны (1939-1940) и Великой Отечественной войны (1941-1945). Эти тексты позволяют судить не только, собственно, о феномене смерти на войне, но также о том, каким образом смерть осмыслялась, о влиянии религии и идеологии, о моральном опыте отношения к событию смерти. При этом надо отметить, что имеющаяся практика анализа такого рода документов по большей части выявляет лишь ценности, сформированные советской идеологией, не принимая во внимание влияния религиозной культуры.

Ключевые слова: событие смерти, война, страх смерти, оправдание смерти, военные письма, религиозная культура.

This paper analyzes soldiers' ruminations in their private correspondence about the death at war as an 'event' from the philosophical and anthropological perspective. It aims at recovering the value orientations and the moral principles, which are operative in their reflection about death. Conceptually, this research relies on the works of Petar

1 Исследование выполнено за счёт гранта Российского научного фонда (проект №20-18-00240). 
Bojanić, Georg Simmel, Ivan Ilyin, Emmanuel Lévinas and Jürgen Habermas. The analysis focuses on the published letters of soldiers who took part in the Soviet-Finnish war (1939-1940) and the Great Patriotic War (1941-1945). These texts shed light on the perception of death at war, conceptualizations of the death-related moral experience, the impact of religion and ideology on soldiers' reflection on death. It should be noted that the existing practice of analysis of such documents puts the main emphasis on the values formed by the Soviet ideology neglecting the impact of religious culture.

Key words: event of death, war, fear of death, justification of death, war correspondence, Soviet ideology, Orthodox culture.

\section{Введение}

Этика войны как проблема, как правило раскрывается через понятие насилие - насильственные действия, противостояние насилию, оправданное или неоправданное насилие - что позволяет исследователям достаточно отстраненно теоретизировать о ходе и последствиях военных действий. Если же речь заходит о смерти, то очевидно, что придется говорить не просто об абстрактных потерях воюющих сторон, а о гибели конкретных людей, о горе семей, потерявших близких, а также о чувствах и мотивах тех, кто убивал в бою. В этом сложность анализа феномена смерти на войне с точки зрения какой-либо нормативности.

При этом именно событие смерти ставит вопрос о правильном и неправильном в жизни, о подлинном и неподлинном существовании. А осознание смертности открывает или, точнее, являет человеку подлинные ценности, делая абстрактную этику персональным моральным кодексом, прожитым и пережитым. Письма участников военных событий являются в этом смысле уникальными документами, так как в них можно видеть не только переживание страха, страданий и лишений, но также и те ценности, которые не просто утешают, но придают смысл смерти. Таким образом проявляется мировоззренческий горизонт, общий для автора письма и адресата, обнаруживаются сложившиеся практики осмысления и оправдания смерти.

В данном случае - это, как правило, контекст религиозной культуры (или фундированный таковой), так как в ней накоплен и воспроизводится опыт отношения к событию смерти. Новые духовные ценности и символы старой культуры могут сосуществовать бесконфликтно, и в том случае, если очевидно противоречат друг другу. И даже если человек считает себя неверующим, его рефлексия о смерти будет связана с религиозной культурой страны на дискурсивном уровне. Пока не распался контекст «мировоззренчески-религиозного встраивания моральных оснований», позволяющих оценивать свое поведение (Хабермас 2011: 76-96, 85), влияние религиозной культуры будет особенно очевидным. Но и далее, практика морального спора в пределах сложившейся в данной культуре аргументации будет вынуждать осуществлять вну- 
тренний диалог с имеющимся моральным сообществом в рамках сложившихся дискурсов.

Процессы секуляризации XX века вытеснили религию почти из всех сфер жизни общества, в общественном сознании утвердились новые познавательные и нравственные установки, однако в том, что касается персональной рефлексии о смерти «бездомные сыновья и дочери модерна» (Там же) во многом воспроизводят сформировавшиеся в рамках религиозной культуры схемы мышления. Идеология оказывает влияние прежде всего на практики оправдания смерти, ставя вопрос о смысле смерти с точки зрения общества, социальной группы, партии (о связи религии и идеологии см.: Богатырев 2019). Однако и в этом случае можно видеть влияние религиозного опыта осмысления смерти, который отражается в культуре похорон и сохранения памяти о погибших.

Сосуществование разных символических рядов религиозного / православного и идеологического/советского воспроизведено в рассказе Андрея Платонова в «Взыскание погибших», где автор очень точно передает предельность переживания смерти, ее тотальность и трагедию матери, потерявшей детей, которых убили злодейски и похоронили коекак. Глаза этой женщины видят «святой город Киев» (Платонов 2012: 217), осиновый крест из двух веточек, а думает она о том, что скоро «наши» придут и «пусть опять будет советская власть» (Там же: 219). Текст стилистически близок к религиозному, притчевому рассказу что символически связывает жертв этой войны с теми, кто погиб в прошлых войнах России, подчеркивают вневременность события смерти. В гениальном произведении Платонова можно видеть какие аспекты переживания смерти актуализируют религиозную практику рефлексии о смерти, и то, каким образом складываются новые практики ее оправдания в советской идеологии. При этом надо принять во внимание, что рассказ написан в годы войны, а его автор ушел на фронт добровольцем. Текст очевидно отражает рефлексию автора по поводу жертв войны, смерти мирных жителей. В этом плане произведения писателей и поэтов, которые участвовали в боевых действиях являются также свидетельствами события войны, в которых в художественной форме отражен имеющийся на тот момент у автора опыт осмысления ключевых экзистенциальных вопросов.

Предполагается, что в военной корреспонденции мы обнаружим такой же образ события смерти на войне. Можно согласиться с Алексеем Голубевым и Сергеем Ушакиным, что письма «нарративно законченные и эстетически замкнутые произведения» (Голубев, Ушакин 2016: 13), где воплощены не только личные, переживания автора, но и нравственные основания, влияющие на отношения к смерти. Выявленные реакции, рефлексии и практики оправдания смерти позволят осуществить реконструкцию этосов участников военных событий в ситуации переживания события смерти. 


\section{Как читать письма о смерти: проблема анализа военной корреспонденции}

В сложившихся политиках памяти военная корреспонденция имеет статус важнейшего источника, свидетельство войн, требующего сохранения и изучения. В настоящее время можно видеть достаточно большое количество публикаций, в которых используются письма участников войны в качестве материала исследования. Помимо этого, есть немало сборников, где под определенными тематическими рубриками представлены письма воевавших и их близких (Письма с войны 2018). И в том, и в другом случае авторы и составители вынуждены определять свою исследовательскую позицию, оговаривать право читать и публиковать письма, использовать их в определенном контексте. В целом можно так описать основные проблемы и подходы. Во-первых, несмотря на то, что писем много, очень сложно рассматривать их как систематически организованный эго-документ. Это не дневник или автобиография. Человек может успеть отправить лишь несколько писем до своей гибели. По ним невозможно представить год или месяцы войны. К тому же может быть очень мало информации об авторе письма. Такая вторичная анонимность и фрагментарность документов склоняет исследователей к особому фокусу видения: не вписывать содержание в общеисторический контекст, а акцентировать внимание на уникальности переживаний и мыслей, на непосредственности впечатлений.

Во-вторых, военная корреспонденция - это документы, которые подвергались пристальной цензуре. И поэтому факты, которые там представлены не всегда соответствовали действительному положению вещей, так как авторы знали о том, что письма будут прочитаны не только родными ${ }^{2}$. К тому же почта работала плохо, и воюющие писали, не получая ответа очень долго.

В-третьих, если приходится работать с готовыми подборками писем, то приходится принимать во внимание авторскую позицию составителей, которые в одном случае видят в этих документах подтверждение репрезентированному в идеологии образу данной войны, в другом напротив стремятся показать прежде скрытые факты военной реальности. Как указывает Татьяна Воронина, «в 1960-е годы сложился устойчивый образ письма с фронта, который активно воспроизводился в течение последующих лет. Смысл, который приобрели письма в эти годы, отныне присутствует в большинстве советских официальных презентаций, впрочем, и в современных российских тоже» (Воронина 2011: http). В этой связи можно отметить и другие тематические рамки представле-

2 В период Великой Отечественной войны письма представляли собой просто листы бумаги, сложенные треугольно, чтобы написать адрес, так называемые «военные треугольники». 
ния писем. Таков подход составителей фундаментального издания $X X$ век: письма войны (ХХ век: письма войны 2016), в котором предлагается посмотреть на письма участников разных войн как на презентацию феномена военной повседневности (материал структурирован по разделам: быт войны, гнет войны, романы войны и т. п.). Редакторы подчеркивают, что стремятся «избежать традиционного стремления видеть в письме лишь повод для герменевтического упражнения или источник крупиц фактов для позитивистской версии истории» (Голубев, Ушакин 2016: 20). Православной религии и деятельности церкви посвящены сборники (Бог и победа 2015; Война и вера 2019), составители которых стремились дать представление о том, как чувствовали себя верующие в советской армии, какие нравственные дилеммы решали. При этом надо отметить, что, хотя используются воспоминания и письма религиозных людей, их оценка отношения к вере в армии достаточно сильно разнятся. Комментаторы военной переписки не скрывают этих различий, показывая тем самым неоднозначность представленной темы.

И, наконец, исследователи отмечают особую специфику писем, авторы которых знают о том, что погибнут в ближайшее время: в предстоящем бою или в госпитале. В этой военной корреспонденции есть послания исключительно личные, адресованные родным, а есть такие, что написаны тем, кто после сражения найдет письмо в вещах погибшего. В последнем случае автор обращается к неизвестному читателю, предполагая, что близкие получат не только это письмо, но и узнают обстоятельства гибели автора. Есть также письма, которые были написаны как обращение к выжившим, своего рода завещание. Также в аспекте изучения практик оправдания смерти важными являются послания, написанные теми, кому пришлось хоронить погибших. Особенность предсмертных и посмертных писем заключается в том, что в них с одной стороны отражены предельные в своей субъективности переживания страх и поиск смысла смерти, с другой стороны, выражаются эти сложные чувства и мысли очень скудным языком. Можно согласиться с Ириной Сандомирской, «излюбленная литературой “правда жизни” или “поэтика войны” <...> являет себя как будто бы отрицая себя: в банальности мысли, в бедности желания, в неаутентичности языка» (Сандомирская 2016: 781).

Как возможно использовать письма для заявленного философского анализа? В данном случае эти документы будут рассматриваться как свидетельства индивидуального морального опыта войны. При этом война понимается как экзистенциальная ситуация, которая является вызовом сложившимся нормативным стратегиям поведения, актуализирует наиболее значимые в персональном жизненном горизонте практики понимания и оправдания. Такого рода реакции отражаются в письмах участников военных событий. Методологически значимым для нас будет подход Петара Боянича, предполагающий выявление в процессе 
чтения текста тревожащих амбивалентностей - Свой / Чужой, другой / Другой, Враг / Друг. (см.: Боянич 2018). Трактовка события смерти в текстах Георга Зиммеля, Ивана Ильина и Эммануэля Левинаса позволит выявить особенности отношения человеку к событию смерти, а понимание Юргеном Хабермасом связи ценностных ориентаций и коммуникации будет актуально для изучения указанных эго-документов.

\section{Реакции: страх, страдание и Другой}

Страх смерти в традиции танатологического философствования трактуется, как конституирующее понимание подлинного существования переживание. Именно страх смерти «высвечивает» смысл жизни, то, ради чего стоит жить. Зиммель в работе «К вопросу о метафизике смерти» отмечает, что «живи мы вечно, наша жизнь осталась бы, вероятно, совершенно неотделимой от своих ценностей и содержаний» (Зиммель 2006: 163). Чтобы жизнь можно было бы помыслить, как цель и ценность «жизнь должна сначала их идеально отрешить от себя», чему способствует осознание ее конечности (Там же). То есть человек, который испытал страх смерти, начинает другую жизнь, следуя новым нравственным ценностям, которые стали для него очевидными в результате экзистенциального кризиса.

Применительно к ситуации войны можно видеть, что эта логика ценностного перерождения нарушена. Страх смерти важен в ретроспективе жизни, важен для живущих и выживших. Однако на войне человек иногда вынужден признать, что у него нет будущего, нет надежды выжить, и новый ценностный порядок, открывшийся ему в страдании страха, останется невостребованным.

«Я решил вам написать последнее письмо, пока жив, ну ничего не поделаешь, нас бьют, не мало людей каждый день, но я еще жив. На фронте еще не был. Но теперь меня скоро убьют, находимся на опасном фронте» — 1941 год, Мамаевз (ХХ век: письма войны 2016: 301).

В этом письме-прощании отражено очень ясно принятие факта смерти, ее неминуемое приближение, а также страдание от неопределенности самого момента гибели. И это тоже вне логики экзистенциального обновления личности вследствие потрясения от страха смерти, которая предполагает, что острота переживаемого не должна нивелироваться в продолжительном ощущении. Страх потрясает, и только таким образом изменяет человека. У этого состояния особый темпоральный режим: мгновения ужаса и вся жизнь проносится перед глазами в один момент. Симптом возвращения к обычному течению времени: рефлексия о про-

3 В некоторых источниках инициалы автора письма не указаны. 
шлом и планы будущей жизни. Как точно пишет Иван Ильин в работе «О смерти»: «Бывают в человеческой жизни такие дни и минуты, когда человек внезапно видит смерть перед собой. Ужасные минуты. Благословенные дни (курсив мой - E. Ч.)» (Ильин 1994: 339). То есть можно ожидать, что за минутами страха смерти наступят дни, позволяющие размышлять о важности этого события, о правильной или благой жизни. Обыденность смерти на войне в том, что она явлена не в мгновении или минуте, а постоянно присутствует. Каждый день и час войны подтверждают, что смерть рядом: риск боев, физические лишения.

«Нахожусь в самом адском положении - смерть на каждой минуте. Нужно иметь большое счастье, чтобы остаться живым в этом проклятом аду, конца войны не видно» - 1942 год, П. Т. Гадеикий (ХХ век: письма войны 2016: 306).

И при этом каждый день воюющие видят, что сегодня кто-то избежал смерти, как-то спасся, но почему и как это случилось понять невозможно. Переносить такое очень тяжело, и как можно прочесть в нижеприведенном отрывке, перенесенные страдания лишают человека всего человеческого.

«Я сейчас переживаю в огне и стуже, если жив останусь, то буду не человеком. Живите как можно лучше, вот теперь я пропал, ничего не надо, всего хватает - голода, холода и огня, только хлебай. Нахожусь на передовой линии фронта. Пишу вам в окопе и слезы льются» — 1941 год (Там же: 301).

Мгновения ужаса, хотя уже пережиты, но не исчерпаны, а возвращаются в страдании, которое не дает «сбежать мыслям» в будущее или прошлое, вынуждает быть здесь и сейчас. Как пишет Э. Левинас «Есть в страдании отсутствие всякого прибежища, прямая подверженность бытию. Оно в невозможности сбежать или отступить. Вся острота страдания - в невозможности отступления. Это загнанность в жизнь, в бытие» (Левинас 1998: 68). Но так «быть» и «жить»- слишком тяжело и поэтому реакцией на невозможную длительность страха становится вопрошание не о смысле жизни, а о смысле такой смерти. Этот вопрос еще не рефлексия, не «введение» к моральной конструкции оправдания, это принятие смерти: пусть умру на войне, но не так же, даже не удостоившись похорон и памяти.

«Что будет завтра, сказать трудно, буду ли жив или мертв, валяться в кустах, как до сего времени валяются трупы. Смерть приходит неожиданно и там, где меньше всего ее ожидают» - 1939 год, М. Мишин (ХХ век: письма войны 2016: 786).

«Плохо в том, что бойцов не зарывают, так и валяются, потому что мы воюем по лесам...» (Там же: 301$)$. 
Трупы погибших, мимо которых проходит армия - это страшная повседневность войны. Так смерть Другого входит в собственное/мое событие смерти.

«17 декабря под д. Ловец был убит Саша Бузановский. В страшном бою погибли еще многие. И я не выдержал. У меня появился нервный тик. При визге немецкой мины или снаряда меня трясло, при близком разрыве тело невольно сжималось и горло схватывали спазмы. [...] А меня охватил самый настоящий страх, ужас близкой смерти. Я боялся смотреть на труп Саши, лежащий рядом с землянкой в ожидании похорон, но я нем мог оторвать глаз от лица покойника, проходя мимо. И за какие-то пять дней я стал стариком» — 1944 год (Подборка писем с фронта: http).

В отличие от других событий жизни над смертью «субъект не властен, относительно которого субъект более не субъект» (Левинас 1998: 69). Но примиряясь с невозможностью избежать скорой гибели во время военных действий, человек все же стремиться сохранить свою субъектность по отношению к событию смерти, и заботиться о смерти настолько, насколько это возможно. Сами письма на пороге смерти являются проявлением такой заботы, ведь авторы обращаются к живым. В описании драматизма своей жизненной ситуации они находят утешение в том, что выжившие узнают о том, что они чувствовали, их опасения и страхи. Вместе с тем такое письмо - это социальное действие, которое совершается, чтобы управлять событием смерти, ввести его в контекст культурных практик прощания, завещания, похорон и памяти о погибших на войне.

\section{Рефлексии и практики оправдания: прощание и прощение}

Вопрошание о смысле такой смерти - на войне, без похорон, без почестей - является условием рефлексии по поводу будущего после смерти. Как указывает, Зиммель, смерть «устанавливает конечность жизни и вечность содержания» (Зиммель 2006: 163), таким образом идея вечной жизни естественным образом трансцендируется над антитезой жизни и смерти, в ней «жизнь обретает себя самое и достигает своего высшего смысла» (Там же: 162). При этом важно отметить, что речь идет не о будущем тех, кто останется живым после войны, не об утешительном тезисе, что «жизнь продолжается», а о вечной / будущей жизни того, кто умирает.

Собственно, солдаты пишут в будущее, понимая, что письмо будет идти долго, и возможно автора уже не будет в живых. Как подчеркивает И. Сандомирская «“Еще” и “уже”: показатели времени и места в хронотопе войны. В грамматике такая структура времени ("когда вы получите... уже буду" [...]) называется futurum perfektum или futurum exactum (курсив И. Сандомирской-E. Ч). будущее еще не наступило, но уже 
совершилось. Событие, которое еще не случилось, но уже произошло» (Сандомирская 2016: 783). По текстам писем можно видеть, каким мыслиться это будущее после гибели: вечная жизнь бессмертной души и / или вечная память о жертве, благодарность погибшему от выживших на родине.

«Победа конечно должна быть наша, но не скоро, а праздновать ее придется немногим счастливцам. Писать ли адрес вам или нет, жить мне наверняка не придется и письмо ваше застанет меня как жертву отечественной войны» — 1941 год, Козлов (ХХ век: письма войны 2016: 306).

«Жизнь в настоящий момент свою я считаю часами, потому что сейчас нахожусь на передовой линии и с часа на час ждем приказа идти в наступление. Как пойду в наступление, то, наверное, сбудется мой сегодняшний сон - отец строил для меня дом, наверное, будет построен для меня дом вечный.

Ну ничего, милая моя кошечка Анечка, умереть за Родину не позор, но выгонять проклятых извергов из нашей родной земли надо обязательно, а война без потерь не бывает, кому-то надо и умирать. Ну а теперь простите меня во всем, и я вас прощаю также» - 1943 год, Г. Павловский (Там же: 792).

Вышеприведенные отрывки очень показательны с точки зрения представления жизненных миров в горизонте которых может выстраиваться моральная аргументация оправдания своей смерти. В концепте «Отечественной войны» (смерть за Родину не позорна, смерть как принесение жертвы на Отечественной войне) проявляется фундирующее влияние православной культуры. Используемый в советском дискурсе 4 и сохранившийся до последнего времени этот концепт очевидно восходит (что всегда подчеркивалось также в советское время, однако вне религиозного контекста) к идеологии Отечественной войны 1812 года. В то время смысл этого концепта раскрывался через идею миссии России как центра православной культуры. Так что война была не только против врага, который вторгся на русскую землю, а в первую очередь - это была война за веру, против дьявола. «По евангельски ведется война против войны, против греха, против диавола. "Наша брань не противъ крови и плоти, но противъ начальствъ, противъ властей, противъ міроправителей тьмы века сего" (Еф 6, 12)» (Архимандрит Иустин (Попович): http).

Таким образом смерть обретает смысл в отношении ценностей более высокого порядка, чем можно было бы предположить. В письмах в перечислении того, за что жертвует своей жизнью боец, часто на первом месте упоминается родина, потом уже близкие:

«...если не буду в живых, то знай и пусть ребята запомнят, что иду защищать родину, тебя Соня от немецкого поругания и детей от немецкой кабалы» — 1942 год, Г. Манаков (ХХ век: письма войны 2016: 568).

4 О понятии Родина см: (Soboleva 2020; Сандомирская 2004). 
Апелляция к ценности Родины/Отечества оправдывает смерть в более универсальном, всеобщем значении. В такой же проекции мыслиться место погибшего в пантеоне памяти - жертва Отечественной войны. Жертва войны - это военная идеологема, но в некоторых письмах авторам важно подчеркнуть обстоятельства своей гибели: случайная смерть, возможно негероическая, в страдании и лишениях. И поэтому важным является статус войны - Отечественная, дающий надежду на более значимый статус события смерти.

Также можно видеть, что как в письмах воспроизводится сложившаяся практика христианского прощания накануне кончины: надо попросить прощения и простить всех.

«Ну а теперь простите меня во всем, и я вас прощаю также» - 1943 год, Г. Павловский (Там же: 792).

Без прощения, которое надо просить у мира (людей) невозможны православные таинства. Поэтому автору недостаточно послать письмопрощание, важно просить о прощении. Не очевидно, что автор письма православный христианин. Как пишет в своих воспоминаниях участник Великой Отечественной войны и будущий диакон Николай Попович: «К сожалению, ни до войны, ни на фронте, не встречал я верующих людей. Хотя, когда начинался минометный обстрел, многие крестились и говорили: “Господи помоги!” В душе людей вера сохранялась» (Цит. по: Бог и Победа: верующие в великих войнах за Россию 2015: 358). Поэтому упоминание «дома вечного», желания простить и проститься могло быть также свидетельством того, как рефлексии о событии смерти осуществляется не воцерковленным человеком в символическом горизонте православной культуры.

И, наконец надо отметить, что травматичность образа брошенных на поле боя тел погибших, приводит к признанию особой ценности правильного, традиционного погребения в условиях военных действий. Когда родным пишут однополчане погибшего, не так подробно описываются обстоятельства гибели, как то, где и как был похоронен боец. Заботиться о смерти - это значит соблюсти все нормы отношения к мертвому телу, которые репрезентированы в практиках захоронения.

«Хоронили на 3-й день после смерти. Был хорошо одет и красиво убран гроб. Весь офицерский состав был собран в клуб провожать и проститься с дорогим и заботливым капитаном Решетниковым, а также было очень много гражданского населения» — 1944 год, Д. Нестерова, Н. Воевода (XX век: письма войны 2016: 795).

«Ваш брат — капитан моей части Решетников Владимир Тимофеевич убит в ночь на 2 мая. С воинскими почестями мы похоронили его. Хорошо устроили могилу. Сделали загородочку. Поставили колонку - памятник с надписью на медной дощечке» — 1944 год, Соловьев (Там же: 793). 
«Из того места, где похоронен Владимир Тимофеевич, я ушел. Уход за могилой и поддержание порядка поручил надежным людям. Мы свято охраняем места, где похоронены наши боевые товарищи. Об этом не беспокойтесь» - 1944 год, Соловьев (Там же: 794).

В этих фрагментах также можно видеть, что описание похорон отражает смешение православных и советских практик прощания и захоронения. «Хоронили на 3-й день» - важно сообщить близким, что сделали как положено по православному обычаю, предполагающему, что хоронить нужно на третий день, так как только через три дня после кончины окончательно обрывается связь души и тела. Но тут же мы читаем, что прощание было в клубе, где фактически, как в храме теперь положено проводить церемонию прощания. Убранство гроба, обустройство могилы, уход за могилой - все это также воспроизводство традиционных культурных практик, которые становятся особенно значимыми в условиях, когда их крайне сложно соблюсти.

«Ваня из автомата сразил 16 фрицев, но, когда поднялся, чтобы бросить гранату по трем гитлеровцам, которые с пулеметом залегли за камнем, был сражен коварной пулей врага. Я послал одного из бойцов, которому приказал вынести его, но только он стал подползать, как тоже был ранен. И только третьему бойцу удалось взять Ванины документы. А хоронить пришлось там, где он стойко и отважно защищал свою родную Карельскую землю» - 1944 год, П. Горбань (Там же: 799).

Здесь описана необъяснимая с точки зрения здравого смысла ситуация - солдаты рискуют жизнью ради того, чтобы похоронить, чтобы не оставить труп погибшего врагам. Очевидно, что, принимая решения выносить тело умершего, командир хотел показать, что подвиг не будет не отмечен, что герой не должен остаться без похорон. Так в заботе об умершем, как уже говорилось выше, проявляется стремление управлять смертью, а также надежда на то, что и собственная смерть станет предметом чье-то заботы и памяти. Похороны репрезентируют событие смерти не как персональное, но как социальное, смысл которого раскрывается только в связи с другими.

\section{Смерть врага: убийство и ненависть}

Война всегда предполагает убийство, а значит у того, кто воюет должна быть достаточно решимости, чтобы сделать это. Не имеющий, как правило, возможности управлять событием собственной смерти солдат, призван на войну, чтобы убить Другого, который должен быть признан и принят как совершенно Другой, как враг. «Не позволительно убивать; но убивать врагов на войне - законно, и похвалы достойно. Так великих почестей сподобляются доблестные в брани, и воздвигаются им 
столпы, возвещающие превосходные деяния» (Афанасий Великий 19021903: 366-369) - так в христианской традиции трактовалась Афанасием Великим известная евангельская заповедь.

Враг - это тот, кого нужно ненавидеть, чтобы пойти на убийство. Ненависть питается состраданием тому, кто был убит или замучен врагом, возмущением, что враг полагает себя вправе лишать жизни и причинять мучения. «Человек не может ненавидеть, не обнаруживая, что носитель негативной ценности по общей оценке занимает или притязает на то место, которое согласно объективному порядку, предписанному вещам порядком их любведостойности, подобает носителю ценности, или же что благо низшего разряда занимает место блага высшего разряда (и наоборот)» — пишет Макс Шелер (Шелер 1994: 369). В ценностном порядке, в рамках которого человеку приходится осуществлять рефлексию по поводу близкой гибели, смысл собственной смерти и смысл смерти врага взаимосвязаны.

«Ему надо было жить. Сволочи немцы лишили его жизни, это для меня больно, так же, как и для вас, дорогая Елизавета Ефимовна. Я отомщу за него немцам» - 1944 год, С. Шелковников (ХХ век: письма войны 2016: 802).

«Побывав на фронте, я научился многому. Я увидел сожженные города и села, расстрелянных и истерзанных невинных женщин, стариков и детей, у меня появилась неимоверная злоба к врагу, а вместе с ненавистью пришли смелость и находчивость» — 1944 год, Т. Вербиикий (Там же: 567).

«Уже посмотрел немецкие зверства и горю ненавистью к каждому немцу и не погибну, если не убью как можно больше немцев» - 1942 год, Г. Манаков (Там же: 568).

При этом важно подчеркнуть, что авторы указывают на важную последовательность «уже посмотрел» и / после «горю ненавистью». То есть ненавидеть надо за что-то, надо пережить и осмыслить увиденное, чтобы быть уверенным в своей ненависти. Эта прожитая и пережитая ненависть уже не только результат идеологической работы, не результат лозунгов, которыми сопровождались военные действия советских войск 5 .

Вот, пример совершенно обратный — школьник 9 класса пишет брату о ненависти финнам:

«Шура, если можно, то напиши, что у вас там с Финляндией. — Я как только услышал, что Финляндия лезет со своим свиным рылом в наш Советский огород, я тут же стал к ним питать ненависть. И ответил тем, что поступил в комсомол» - 1939 год, Н. Чистяков (Там же: 563).

5 См. об этом, к примеру: (Зверев, Сторожев 2014: 21-28). 
На страницах газет о ненависти к немецким захватчикам писали Алексей Толстой (Толстой 1941) и Илья Эренбург (Эренбург 1942). «Наука ненависти» - это название рассказа Михаила Шолохова (Шолохов 1942), опубликованного ровно через год после нападения Германии на СССР. Писатель публикует произведение с эпиграфом из приказа И. Сталина том, что без ненависти не победить врага. Повествование начинается с образа смерти ненавистных врагов, мертвые тела которых описываются натуралистично и пренебрежительно. Несмотря на эти усилия пропаганды в тех письмах, где воюющие пишут особенно ярко о собственных страданиях и предчувствии близкой гибели, нет ничего о ненависти ${ }^{6}$.

«Счастлив тот человек, который не видел и не увидит этой проклятой войны, какие здесь переживания переносишь...» - 1941 год, Миронов (ХХ век: письма войны 2016: 301).

Вышеприведенные слова можно отнести к любым войнам, к прошлым и современным, война ужасна, она причиняет нечеловеческие страдания. Ситуация смертельного ужаса, длительность этого переживания замыкает человека на собственной жизни, и смерть Другого - это все равно возвращение к событию своей смерти. Ненависть предполагает прилив сил, как пишет один из бойцов -

«с ненавистью пришли смелость и находчивость»-1944 год, Т. Вербицкий (Там же: 567).

В то время как в страдании от страха смерти нет никакой опоры, нет источника силы «моя мужественность, героизм меня как субъекта не могут быть по отношению к смерти ни мужественностью, ни героизмом. Уже в страдании, в недрах которого было схвачено это соседство со смертью. Активность субъекта оборачивается пассивностью» (Левинас 1998: 72).

И только в акте рефлексии о смысле своей смерти, когда становится важным понять за что приходится умирать, важным аргументом оправдания смерти становится миссия защитника от врага. Смерть врага оправдывает, делает жертву не напрасной. Ненависть превращает противника во врага, абстрактного Другого, в того, кто заслужил смерти. Защищать Отечество - это уничтожать врага, такова моральная аргументация в ситуации осмысления ценности/ смысла собственной смерти и права убийства другого человека.

6 В 1941 году «за период с 15-го по 31-е октября с. г. 6 отделением ВЦ особого отдела НКВД 34 армии было прочитано 119325 писем, исходящих от бойцов, командиров и политработников 34-й армии Северо-Западного фронта. Из общего количества прочитанной корреспонденции отмечено 1266 документов, отражающих упаднические настроения отдельных военнослужащих» (XX век: письма войны 2016: 300). В статье цитируются в том числе и эти письма, так что можно видеть, сколько воевавших не писали о ненависти, а прежде всего описывали свои страхи и страдания. 


\section{Выводы}

Таким образом, для понимания персонального морального опыта отношения к смерти на войне, как показал проведенный анализ, важно видеть существенную трансформацию, которую претерпевает логика экзистенциального обновления в результате осознания собственной конечности. Длительность переживания страха смерти, физические и духовные страдания, ясное ощущение неминуемости близкой смерти приводят человека к необходимости осуществить рефлексию о смысле такой смерти - в бою, возможно даже без погребения. Будущее мыслиться как будущее после смерти — вечная жизнь бессмертной души и / или вечная память выживших.

Убийство врага, как видно из представленных писем, описывается как следствие ненависти, возникшей от сострадания погибшим и замученным. Ненависть осознается также лишь в рефлексии, где смысл собственной смерти и смерти врага оказываются взаимосвязанными.

В скудости письменной речи рассмотренных документов нет откровения, нет никакой оригинальной философии реального участника войны, так как вынужденный рефлексировать о смерти в тяжелейшей жизненной ситуации, человек использует в моральном оправдании собственной гибели те практики аргументации, которые имеются и обладают значимостью, от этого происходит смешение дискурсов советской и православной культуры. В этой связи, как мы видим, актуальным является концепт Отечественной войны, который в своих истоках восходит к православной практики оправдания войны. Стремление сохранить свою субъектность по отношению к событию смерти проявляется в самом жанре письма-завещания, где оговаривается статус смерти - жертвы Отечественной войны. Также особую значимость для участников военных событий приобретает соблюдение традиций похорон, в описании которых также наблюдается указанное выше смешение дискурсов, свидетельствующее в том числе о фундирующем влиянии православной культуры.

\section{ЛИТЕРАТУРА}

Архимандрит Иустин (Попович). Толкование на Евангелие от Матфея (главы 16-25, 27-28).

Афанасий Великий. «Послание к Аммуну монаху». Творения иже воо святых отияа нашего Афанасия Великаго, архиепископа Александрийского. Сергиев Посад: свято Сергиева Лавра собственная тип., 1902-1903: 366-369.

Бог и Победа: верующие в великих войнах за Россию. Москва: Эксмо, 2015.

Богатырев Дмитрий Кириллович. Религии и идеологии. Санкт-Петербург: Русская христианская гуманитарная академия, 2019.

Боянич Петар. Насилие и мессионизм. Екатеринбург; Москва: Кабинетный ученый, 2018. 
Война и вера. Свидетельства очевидиев. Москва: Фонд социокультурных проектов «Традиция», 2019.

Воронина Татьяна. «Личная корреспонденция и память о Второй мировой войне». Неприкосновенный запас 3 (2011): 159-175. URL: https://magazines.gorky.media/ nz/2011/3/kak-chitat-pisma-s-fronta.html

Голубев Алексей, Ушакин Сергей. «Экс-позиция письма». ХХ век: письма войныл: антология военной корреспонденции. Москва: Новое литературное обозрение, 2016: $8-21$.

Зверев Сергей, Сторожев Николай. «Воспитание ненависти к врагу в советской воинской культуре 30-40-х гг. ХХ в.». Вестник СПбГУКИ 20/3 (сентябрь 2014): 21-28.

Зиммель Георг. «К вопросу о метафизике смерти». Зиммель Георг. Избранные работы. Киев: Ника-Центр, 2006: 158-171.

Ильин Иван. «О смерти (письмо первое)». Ильин Иван. Собрание сочинений. В 10 т. Т. 3. Москва: Русская книга, 1994: 336-340.

Левинас Эммануэль. «Время и другой». Левинас Эммануэль. Время и другой. Гуманизм другого человека. Санкт-Петербург: Высшая религиозно-философская школа, 1998.

Письма с войны: сборник документов из фондов КОГБУ «ГАСПИ КО»/ под ред. Е. Н. Чудиновских. Киров: ООО «ВЕСИ», 2018.

Платонов Андрей. «Взыскание погибших». Платонов Андрей. Смерти нет! Рассказы и публииистика 1941-1945 годов. Москва: Время, 2012: 213-220.

Подборка писем с фронта. ГКУ РО «ГАРО». URL: http://gosarhro.ru/dates-events-people/ the-letter/selection-of-pise/

Сандомирская Ирина. «'Мы уезжаем, куда неизвестно, только не скучайтесь’: читая чужие письма». $X X$ век: письма войны: антология военной корреспонденщии. Москва: Новое литературное обозрение, 2016: 779-783.

Сандомирская Ирина. «Родина в советских и постсоветских дискурсивных практиках». Интеракция. Интервью. Интерпретаиия 2-3 (2004): 16-26.

Толстой Алексей. «Я призываю к ненависти». Правда 28.07.1941: 3.

Хабермас Юрген. «К архитектонике дифференциации дискурсов». Хабермас Юрген. Между натурализмом и религией. Москва: Весь мир, 2011: 76-96.

ХХ век: письма войны: антология военной корреспонденции. Москва: Новое литературное обозрение, 2016.

Шелер Макс. «Ordo amoris». Шелер Макс. Избранные произведения. Москва: «Гнозис», 1994: 339-396.

Шолохов Михаил. Наука ненависти. Москва: Издательство «Правда», 1942.

Эренбург Илья. «О ненависти». Красная звезда 05.05.1942: 4.

Soboleva Maja. Ist “'Heimat' ein Mythos?: Der Heimatbegriff zwischen Bezeichnung und Bedeutung”. Deutsche Zeitschrift für Philosophie 68/4 (2020): 514-531.

\section{LITERATURE}

Arhimandrit Iustin (Popovich). Tolkovanie na Evangelie ot Matfeya (glavy 16-25, 27-28).

Afanasij Velikij. «Poslanie k Ammunu monahu». Tvoreniya izhe voo svyatyh otca nashego Afanasiya Velikago, arhiepiskopa Aleksandrijskogo. Sergiev Posad: svyato Sergieva Lavra sobstvennaya tip., 1902-1903: 366-369.

Bog i Pobeda: veruyushchie v velikih vojnah za Rossiyu. Moskva: Eksmo, 2015.

Bogatyrev Dmitrij Kirillovich. Religii i ideologii. Sankt-Peterburg: Russkaya hristianskaya gumanitarnaya akademiya, 2019.

Boyanich Petar. Nasilie i messionizm. Ekaterinburg; Moskva: Kabinetnyj uchenyj, 2018.

Vojna i vera. Svidetel'stva ochevidcev. Moskva: Fond sociokul'turnyh proektov «Tradiciya», 2019.

Voronina Tat'yana. «Lichnaya korrespondenciya i pamyat' o Vtoroj mirovoj vojne». Neprikosnovennyj zapas 3 (2011): 159-175. URL: https://magazines.gorky.media/nz/2011/3/kakchitat-pisma-s-fronta.html 
Golubev Aleksej, Ushakin Sergej. «Eks-poziciya pis'ma». XX vek: pis'ma vojny: antologiya voennoj korrespondencii. Moskva: Novoe literaturnoe obozrenie, 2016: 8-21.

Zverev Sergej, Storozhev Nikolaj. «Vospitanie nenavisti k vragu v sovetskoj voinskoj kul'ture 30-40-h gg. XX v.». Vestnik SPbGUKI 20/3 (sentyabr' 2014): 21-28.

Zimmel' Georg. «K voprosu o metafizike smerti». Zimmel' Georg. Izbrannye raboty. Kiev: Nika-Centr, 2006: 158-171.

Il'in Ivan. «O smerti (pis'mo pervoe)». Il'in Ivan. Sobranie sochinenij. V 10 t. T. 3. Moskva: Russkaya kniga, 1994: 336-340.

Levinas Emmanuel’. «Vremya i drugoj». Levinas Emmanuel’. Vremya i drugoj. Gumanizm drugogo cheloveka. Sankt-Peterburg: Vysshaya religiozno-filosofskaya shkola, 1998.

Pis'ma s vojny: sbornik dokumentov iz fondov KOGBU «GASPI KO»/pod red. E. N. CHudinovskih. Kirov: OOO «VESI», 2018.

Platonov Andrej. «Vzyskanie pogibshih». Platonov Andrej. Smerti net! Rasskazy i publicistika 1941-1945 godov. Moskva: Vremya, 2012: 213-220.

Podborka pisem s fronta. GKU RO «GARO». URL: http://gosarhro.ru/dates-events-people/ the-letter/selection-of-pise/

Sandomirskaya Irina. «"My uezzhaem, kuda neizvestno, tol'ko ne skuchajtes”: chitaya chuzhie pis'ma». XX vek: pis'ma vojny: antologiya voennoj korrespondencii. Moskva: Novoe literaturnoe obozrenie, 2016: 779-783.

Sandomirskaya Irina. «Rodina v sovetskih i postsovetskih diskursivnyh praktikah». Interakciya. Interv'yu. Interpretaciya 2-3 (2004): 16-26.

Tolstoj Aleksej. «Ya prizyvayu k nenavisti». Pravda 28.07.1941: 3.

Habermas Yurgen. «K arhitektonike differenciacii diskursov». Habermas Yurgen. Mezhdu naturalizmom i religiej. Moskva: Ves' mir, 2011: 76-96.

XX vek: pis'ma vojny: antologiya voennoj korrespondencii. Moskva: Novoe literaturnoe obozrenie, 2016.

Sheler Maks. «Ordo amoris». Sheler Maks. Izbrannye proizvedeniya. Moskva: «Gnozis», 1994: 339-396.

Sholohov Mihail. Nauka nenavisti. Moskva: Izdatel'stvo «Pravda», 1942.

Erenburg Il’ya. «O nenavisti». Krasnaya zvezda 05.05.1942: 4.

Soboleva Maja. Ist "Heimat" ein Mythos?: Der Heimatbegriff zwischen Bezeichnung und Bedeutung. Deutsche Zeitschrift für Philosophie 68/4 (2020): 514-531.

\section{Јекатерина Черепанова}

\section{СМРТ У РАТУ У ЛИЧНОЈ КОРЕСПОНДЕНЦИЈИ РУСКИХ УЧЕСНИКА РАТА 1939-1945. ГОДИНЕ: РЕАКЦИЈЕ, РЕФЛЕКСИЈА И ПРАКСА ОПРАВДАВАҢА}

\section{Резиме}

Рад има за циљ да средствима философско-антрополошке анализе представи особености доживљаја смрти у рату да би се разоткрила потенцијална вредносна оријентација која би омогућила да се суди о моралним основама рефлексије о смрти и пракси њеног оправдавања. За дати аспект од методолошког значаја ће бити приступ П. Бојанића, Г. Зимела, И. Иљина, Е. Левинаса и Ј. Хабермаса. Корпус истраживања чине писма учесника Совјетско-финског (1939-1940) и Великог отаџбинског рата (1941-1945), објављена у различитим издањима. За разумевање личног моралног искуства односа према смрти у рату, како је показала анализа, важно је испратити суштинску трансформацију којој подлеже логика егзистенцијалног обнављања након спознаје сопствене коначности. Трајање доживљаја страха од смрти, физичка и духовна патња, јасан осећај неминовности блиске смрти доводе човека до потребе да рефлектује о смислу такве смрти - у борби, можда чак и без сахране. Будућност се промишља као будућност после смрти - вечни живот бесмртне душе и/или вечно сећање преживелих. 
Убиство непријатеља, како се види из датих писама, описује се као последица мржње, проистекле из сажаљења према погинулим и мученим. Мржња се такође схвата само у рефлексији, где се испоставља да су смисао сопствене смрти и смрти непријатеља узајамно повезани.

У шкртим речима размотрених докумената нема откровења, нема никакве оригиналне философије реалног учесника рата, будући да човек, када је принуђен да рефлектује о смрти у изузетно тешкој животној ситуацији, користи за морално оправдање своје погибије ону праксу аргументације која постоји и која има значај, услед чега долази до мешања дискурса совјетске и православне културе. У вези с тим, како разумевамо, постаје актуелан концепт Отаџбинског рата, који потиче од православне праксе оправдања рата. Тежња да се сачува сопствена субјективност у односу према догађају смрти огледа се у самом жанру писма-завештања, где се разматра статус смрти - жртве Отаџбинског рата. Такође, нарочит значај за учеснике ратних дешавања добија поштовање обреда сахрањивања, у чијим се описима једнако примећује већ наведено мешање дискурса, које сведочи и о постојаном утицају православне културе.

Кључне речи: догађај смрти, рат, страх од смрти, оправдање смрти, војна писма, религиозна култура. 